\title{
Photodynamic therapy in endodontics: literature review.
}

\author{
Maria Cleyde Faria Damasceno (1) e Maria Madalena do Carmo Araújo (1).
}

\section{ARTIGO DE REVISÃO}

Abstract

Endodontic therapy seeks to prevent and when necessary to eliminate endodontic infections. The persistence of microorganisms to the mechanical chemical preparation or the intracanal medication is considered the main cause of the failures of the endodontic treatment. In these cases Enterococcus faecalis is the most commonly found microorganism. Photodynamic therapy (PDT) emerges as a promising adjuvant therapy to conventional endodontic treatment to eliminate these persistent microorganisms. This therapy consists in the association of a specific light source with a photosensitizer in the presence of oxygen, producing cytotoxic species to the microorganisms. Thus, the present article aims at a review of the literature on the use of photodynamic therapy in endodontics, a test that is shown to assist in the preparation of the root canal.

Keywords: Laser; Endodontic; Photodynamic therapy. 


\section{Terapia fotodinâmica na endodontia: revisão de literatura}

\section{Resumo}

A terapia endodôntica busca prevenir e quando necessário eliminar infecções endodônticas. A persistência de microrganismos ao preparo químico mecânico ou a medicação intracanal é considerada a principal causa dos insucessos do tratamento endodôntico. Sendo nestes casos o Enterococcus faecalis o microrganismo mais comumente encontrado. A terapia fotodinâmica (PDT) desponta desta maneira como uma promissora terapia coadjuvante ao tratamento endodôntico convencional para eliminar estes microrganismos persistentes. Esta terapia consiste na associação de uma fonte de luz específica a um fotossensibilizador na presença de oxigênio, produzindo assim espécies citotóxicas aos microrganismos. Assim, o presente artigo tem como objetivo realizar uma revisão de literatura sobre o uso da terapia fotodinâmica na endodontia, a qual demonstra-se efetiva como auxiliar durante o preparo do canal radicular.

Palavras-chave: Lasers; Endodontia; Fotoquimioterapia.

Instituição afiliada: 1- Grupo de Pesquisas Odontológicas da Amazônia, Manaus, Amazônas, Brasil. Dados da publicação: Artigo recebido em 10 de Março, revisado em 15 de Março, aceito para publicação em 20 de Março e publicado em 31 de Março.

DOI: $\underline{\text { https://doi.org/10.36557/2674-8169.2021v3n2p27-40 }}$

@ Maria Cleyde Faria Damasceno damascenocleyde@gmail.com

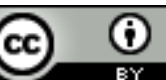

This work is licensed under a Creative Commons Attribution 4.0 International License. 


\section{INTRODUÇÃO}

Endodontics is the science that studies the pulp chamber morphology, the physiology and pathology of the pulp, as well as the prevention, treatment and recovery of its implications in periapical tissues (1). The main objectives of endodontic treatment are to provide an efficient cleaning of the root canal in order to eliminate tissue debris, microorganisms and, at the same time, dilate it so that it is possible to perform an impermeable three-dimensional filling, isolating the canal system from the rest of the organism ( two).

Microorganisms are the main etiological factor of pulp and periradicular pathologies. Thus, during endodontic treatment, maximum disinfection of the root canal system is sought, as well as the prevention of its reinfection. In these cases, Enterococcus faecalis has been the most commonly found microorganism $(3,4,5)$. To achieve these goals, conventional therapy is used, which consists of cleaning and shaping the root canal system using manual or rotary files, along with the irrigation of auxiliary chemicals, and in some cases, it is complemented with intracanal medication (6).

Laser therapy has been used with great success in the dental clinic and currently represents an excellent option available to the health area. Although it is a relatively new technique, the possibilities of using the laser have increased and its use has been widespread in all different areas of medicine and dentistry (7). Photodynamic therapy emerges in this way, as a new therapy, adjuvant to endodontic treatment, in an attempt to eliminate persistent microorganisms to mechanical chemical preparation (8). From English, Photodynamic Therapy (PDT), is based on the association of photosensitizing drugs and a specific light source, such as the low-power laser (9).

Given the above, this article aims to conduct a literature review regarding the use of photodynamic therapy in endodontics.

\section{REVISÃO DA LITERATURA}

A bibliographic review study was carried out with consultation of the following databases: Google Scholar and PubMED. In Google Scholar, the search term: premature birth and malocclusion and dentistry and 2014 and 2015 and 2016 and 2017 and 2018 was used and approximately 34 records were found. In PubMED, the search expression: malocclusion and dentistry and born preterm was used and 08 results were obtained.

Studies and articles published in national and international journals in English and Portuguese were included, with content aimed at the possible repercussions caused by prematurity at birth in dental occlusion, possibly resulting in dental malocclusion.

This study also included considerations of books, monographs, dissertations and theses that had the same theme. 
Studies that did not have content concerning the subject after excluding selective and analytical reading and that had an exclusively medical basis about the manifestations of prematurity were excluded.

\section{REVISÃO DA LITERATURA}

The purpose of endodontic treatment is to prevent and, when necessary, eliminate endodontic infections and allow the apical periodontium to heal. The complexity of the root canal system with its isthmus, branches and dentinal tubules makes complete bacterial debridement almost impossible, even when conventional methods of endodontic instrumentation and irrigation are carried out with the highest technical standards $(4,10)$. In the last decades, endodontics has evolved substantially with the development and adoption of new technologies and materials, facilitating endodontic treatment and reducing the time for its execution. Despite this, most endodontic failures or failures are related to the persistence of microorganisms that have resisted mechanical chemical preparation or intracanal medication (4). Epidemiological data have pointed out that $30 \%$ to $50 \%$ of the failures of conventional endodontic therapy are related to residual and persistent infections, which require supplementary strategies to perform disinfection (3).

Enterococcus faecalis, facultative anaerobic gram-positive bacterium, has been the most commonly found microorganism, due to specific characteristics, such as: ability to colonize dentin and dentinal tubules, which makes its removal difficult by chemical and mechanical means, and may even resisting intracanal medication and irrigating solutions, potential for intratubular invasion even in nutritional scarcity, in addition to presenting some virulence factors $(3,5,11)$. Several studies $(3,5,10)$ have evaluated the antimicrobial capacity of using laser against $\mathrm{E}$. faecalis. The methodology of these studies was quite varied. In this sense, the experiments were carried out in vitro, in bovine and human dentin, hydroxyapatite discs or even a clinical study. Most compared conventional endodontic therapy with the use of laser as an adjunct or alone. What can be observed is that the laser has considerable bactericidal power (5).

Laser technology presents itself as an alternative for medical and dental treatments, with the aim of improving conventional techniques, making it adjuvant to conventional treatment (9). After all, more than $90 \%$ of the available literature reports positive effects from the use of laser therapy used for more than 30 years. However, unfavorable results can occur due to the use of low or high doses, diagnostic error, insufficient number of sessions or the lack of standardization of the frequency of applications (7). For the purpose of complete disinfection, high-powered lasers were used, resulting in $99 \%$ bacterial elimination due to temperature increase and protein denaturation. However, damage to dental tissues and adjacent tissues may be associated with the use of high-powered laser (10,12-14).

In contrast, low-power lasers have a therapeutic effect, that is, they promote tissue repair, inflammation modulation and analgesia. As they do not cause an increase in temperature in the tissue, they have no associated antimicrobial effect. These lasers, however, can present a microbial reduction index in the range of $99-100 \%$ when used in combination with photosensitizing agents. The association of a light source with a 
photosensitizing agent for microbial death is called photodynamic therapy (PDT, in English, Photodynamic Therapy) (13).

The use of lasers in endodontics is not restricted to photodynamic therapy, the use of the Nd: YAG laser has been tested to remove the smear layer from the surface of the root canal, replacing the use of chemical substances, such as EDTA (ethylene diamine tetra acid) -acetic), the most widely used substance (2). The laser was developed and introduced in endodontics in order to promote the apical sealing of the root foramen. Subsequently, the introduction of thin and flexible glass fibers allowed a deep penetration of laser light into the apical third of the root canal (5).

The PDT concept has been known for over 100 years, when Oscar Raab in 1900 published the first article on photodynamic effects, when he observed that low concentrations of acridine dye in the presence of light could be lethal to the parameciums, the protozoan, which causes malaria. The first application in Medicine is attributed to Tappeiner \& Jesionek, in 1903, who used the topical application of the eosin dye and exposure to light to treat skin cancer. In 1907, Von Tappeiner called this phenomenon a photodynamic action. Since then, research in this area has been looking for new photosensitizers and new light sources. Of the therapeutic possibilities using photodynamic therapy, the use of microbial elimination is one of the most discussed today $(9,15)$.

PDT is a new antimicrobial strategy that involves the combination of a non-toxic photosensitizer and a unique visible light source in the presence of oxygen. The transfer of energy from the activated photosensitizer to the available oxygen results in the formation of toxic oxygen species, known as singlet oxygen and free radicals. These are highly reactive chemical species that bind to the bacterial membrane and damage proteins, lipids, nucleic acids and other microbial cellular components. It is important that the light source is absorbed by the dye so that the PDT is effective in making cells unviable $(8,10,16,17)$.

Photodynamic therapy is a photochemical process in which the electronic excitation of the sensitizer causes two mechanisms: type I - electron transfer - and type II - energy transfer. In the type I mechanism, oxidized products are formed and about $5 \%$ of the reaction occurs. In the other 95\%, the type II mechanism occurs, which is more desirable and responsible for apoptosis, which, unlike necrosis, does not cause injury to adjacent tissues. In apoptosis, the cell has programmed death with shrinkage and formation of vesicles that are phagocytosed by macrophages later. As there is no cell lysis, there is no leakage of the cytoplasmic content, thus preventing tissue damage. This makes PDT an effective and safe therapy $(6,15)$.

There are some advantages of PDT over the use of traditional antimicrobials. Cell death mediated by the release of free radicals makes the development of resistance by microorganisms unlikely. As bacterial death is rapid, it is not necessary to maintain the chemical agent for long periods, as is the case with antibiotics. In addition, the therapy is highly selective, with the lesion area being confined by careful topical application of the dye and restriction of irradiation through the use of specific optical fiber (9). 
There is a fundamental difference in susceptibility to antimicrobial photodynamic therapy between gram-positive and gram-negative bacteria. In general, gram-positive bacteria are more susceptible than gram-negative bacteria. Therefore, the structural characteristics of different types of bacteria must be observed. The high susceptibility of gram-positive species can be explained by their physiology. The cytoplasmic membrane is surrounded by a relatively porous layer of peptidoglycan and lipoteichoic acid, which allows the photosensitizer to pass through this membrane (14). Differences in susceptibility to PDT are also observed when the microorganisms are organized in the form of biofilm and when they are arranged as isolated cells, and the challenge of the PDT is greater when the microorganisms are organized in the form of biofilm (9).

Tennert et al. evaluated the effect of photodynamic therapy in cases of primary and secondary infections in the presence of Enterococcus faecalis, concluding that irrigation with $3 \%$ sodium hypochlorite and the combination of irrigation with $3 \%$ sodium hypochlorite with photodynamic therapy led to a reduction significantly higher number of $\mathrm{E}$. faecalis compared to the use of photodynamic therapy alone. In conclusion, photodynamic therapy is an effective complement for disinfecting root canals, especially in cases of retreatment (18).

Sodium hypochlorite $(\mathrm{NaOCl})$ is an irrigating solution predominantly used in endodontic treatment in concentrations ranging from 0.5 to $5.25 \%$, although other alternative solutions have already been studied. The use of chlorhexidine gluconate as an irrigant during the preparation of the root canal system has also been suggested based on its antibacterial effect, substantivity and less cytotoxicity compared to sodium hypochlorite. In the study by Samiei et al., The antibacterial effects of photodynamic therapy were compared with $2 \%$ chlorhexidine and $2.5 \%$ sodium hypochlorite in channels infected with E. faecalis. The results of this study showed that the three antibacterial agents significantly decreased the count of E. faecalis. However, there was no significant difference between therapy and the use of $2 \%$ chlorhexidine. The effectiveness of $\mathrm{NaOCl}$ was superior to the other agents (19).

Different protocols regarding the intensity of laser light, concentrations of photosensitizers and activation methods are still being tested, showing varied results and susceptibility of bacterial species to treatment9. The study by Castro et al. evaluated the isolated action of $1 \%$ sodium hypochlorite, AsGaAl laser, 25\% Endo-PTC azulene dye and photodynamic therapy on cultures of Enterococcus faecalis in vitro, concluding that $1 \%$ sodium hypochlorite was effective in eliminating microorganisms and photodynamic therapy only reduced the number of bacteria. The laser and the dye used in isolation did not exert any activity to inhibit microbial growth (11). It seems to be well established that neither the photosensitizer nor the laser are capable of and produce significant bacterial reduction. It is the combination of both that can activate the therapy mechanism and lead to bacterial death (14).

The first light sources used in PDT were conventional lamps, emitting noncoherent and polychromatic light, with a strong associated thermal component. The development of low intensity diode lasers with monochromatic and coherent light facilitated the association with photosensitizers with a resonant absorption band with the wavelength emitted by the laser (8). The laser most commonly used in PDT studies was 
the Diode laser, with power protocols in the range of $100 \mathrm{~mW}(3,18,20)$. However, a direct comparison between them is difficult, due to the discrepancies between the laser use protocols used in the methodologies5. According to Trindade et al., The activation of the photosensitizer has already been carried out using several lasers, such as argon laser, steam lasers: $\mathrm{Nd}$ : Yag, gold or copper, all complex and expensive equipment. Diode lasers have now become the most widely used due to their low cost and portability. Other lasers, such as light-emitting diodes (LED) or conventional halogen light, have also been used with good results (14). Asnaashari et al. in his study he compared the antibacterial activity of photodynamic therapy using two methods, diode laser and LED lamp, concluding that the use of LED was more effective than the diode laser in reducing E. faecalis (21).

The use of intracanal optical fibers has also been studied as a way to increase the effectiveness of therapy14. For the PDT to be effective, it is essential that the light source interacts with the photosensitizer. Thus, the choice of the light source depends on the photosensitizer that will be used, and vice versa (13).

The photosensitizer is a chemical sensitive to light, the use of photosensitizers for photosensitizing infected tissues can allow the absorption of bacterial cells and irradiation to tissues and result in the destruction of both infected tissues and bacteria (17). The desired properties of an excellent photosensitizer include: low cytotoxicity, short photosensitivity, simplicity in formulation, reproducibility, high stability and high affinity, and penetration into bacterial cells instead of healthy tissues (selectivity) (14). In endodontics, photosensitizers derived from phenothiazines have been widely used in research involving PDT. Phenothiazines are tricyclic heteroaromatic compounds, blue dyes, such as toluidine blue dye and methylene blue. In low concentrations they do not produce cytotoxic action and the dose required for bacterial death is less than the dose to cause damage to cells. Methylene blue has been used as a target for microorganisms in the endodontic microbiota, due to its hydrophilic nature, accompanied by low molecular weight and positive charge, allowing passage through the porin protein channels in the outer membrane of gram-negative bacteria (8). They have a light absorption range between $600-660 \mathrm{~nm}(14)$.

The pre-irradiation time is when the photosensitizer comes into contact with the microorganism so that it can penetrate or, at least, bind to the plasma membrane and, consequently, increase the damage caused to the microorganisms. The most used time in the works was five minutes (6.14). In the applications of antimicrobial therapy, it is expected that the dye will join the microorganism or even go beyond the cell membrane barrier and in this period the photosensitizer does not suffer degradation before activation by the light source (8). The time most used in in vitro work for pre-irradiation was five minutes, however, gram-negative bacteria, as they have a more developed molecular structure, with an outer membrane more than gram-positive ones, need more effective parameters, and should - increase the concentration of the dye or the preirradiation time (6). The depth of irradiation is also considered a critical factor for antimicrobial capacity, since maximum efficiency requires the direct application of laser light on the microorganism (5).

According to Arneiro et al., After selecting 13 studies that exclusively evaluated the performance of photodynamic therapy in reducing $\mathrm{E}$. faecalis, they concluded that the 
therapy has a better antimicrobial effect when used as an adjunct to endodontic treatment with sodium hypochlorite (3). Most studies have not been able to confirm a significant improvement in disinfection for photodynamic therapy as a replacement for current methods of disinfection. Its indication as an excellent adjunct to conventional endodontic therapy is well documented, however the data suggest the need for protocol adjustments or new formulations of photosensitizers to increase the predictability of photodynamic therapy in endodontics $(14,22,23)$.

\section{DISCUSSÃO}

Microbial infection plays an important role in the development of periapical lesions. The elimination of pathological microflora from the root system is one of the main objectives in endodontic treatment. Inadequate disinfection of the root canal system can lead to treatment failure and current techniques for root canal treatment do not always allow this disinfection $(21,24)$. According to Trindade et al., In their literature review, live studies concluded that the combination of photodynamic therapy with conventional mechanical chemical preparation therapy has microbial reduction intervals of $96.7 \%$ to $98.5 \%$, already only for conventional therapy of mechanical chemical preparation this interval increases to $87.7 \%$ to $91 \%(14)$.

The use of intracanal medication in cases of periapical lesions and retreatments is a very usual method in endodontic therapy, mainly aiming at the elimination of microorganisms resistant to the therapy, as is the case of E. faecalis. of calcium with photodynamic therapy. Asnaashari et al., In their study carrying out this comparison, concluded that the number of bacterial colonies after undergoing traditional endodontic treatment in one group applying PDT and in another using calcium hydroxide as medication, concluded that in both groups there was a reduction the number of $\mathrm{E}$. faecalis, but in the group where photodynamic therapy was applied, this reduction was greater (25). In the same way, Borsatto et al. conducted an animal study inducing periapical lesions, where they compared the performance of endodontic treatment in one session with PDT, without the application of therapy and treatment in two sessions with the use of calcium hydroxide as medication. Since the use of calcium hydroxide was shown to be more effective in decreasing the progression of the lesion (26). Ahangari et al. in their study, they showed the same antimicrobial efficacy against E. faecalis and C. albicans using both photodynamic therapy and calcium hydroxide (24).

Garcez et al. investigated the effect of PDT in patients with pulp necrosis and periapical lesions in vivo. They found that PDT as an adjunct to conventional endodontic treatment leads to a significant reduction in bacterial load after irrigation using $\mathrm{NaOCl}$, hydrogen peroxide and EDTA and is effective against bacteria resistant to various drugs. Based on these findings, PDT should have an additional antimicrobial effect after root canal irrigation, especially in resistant microorganisms. Furthermore, they suggest that a second application of PDT is even more effective than the first, probably due to the change in $\mathrm{pH}$ caused by the calcium hydroxide paste and the biofilm formation being less complex compared to the initial formation (27), these results they are also evidenced in the studies by Asnaashari et al. with the use of PDT in teeth that needed retreatment due to the presence of periapical lesions (12). Regarding the performance of a second application of photodynamic therapy, Prazmo et al. confirm in their study an increase of 
almost $50 \%$ in the microbial reduction of infected channels, concluding that photodynamic therapy together with irrigation with sodium hypochlorite, which is still considered the best method, is a promising alternative to endodontic treatment (28).

Blue lights, routinely used in dental practices for photoactivation of resin-based materials, are attractive options for dental therapy. However, despite this potential advantage, the use of blue light may be limited by the lack of an appropriate photosensitizer. They point to some photosensitizers, but suggest more additional tests before their clinical indication (29). An alternative light source for PDT are LEDs (light emitting diodes), which can be used as activation sources in PDT, featuring a low thermal component and monochromatic light, with a narrow band of wavelength. In LEDs, the spontaneous radiation mechanism with little energy for light generation predominates, presenting a broad spectrum of non-coherent light and with greater divergence (8).

According to Poly et al., 2010, despite the discrepancies observed in relation to the extent of irradiation in the root length, there was no significant difference between the studies and none was able to achieve sterilization, which highlights the difficulty of completely irradiating the entire system. root canals (5). One way to guarantee the presence of oxygen during PDT is by coupling an optical fiber to the laser tip, displacing it inside the root canal system in helical movements, from apical to cervical and vice versa, during the entire irradiation process (6).

Recently, studies of photodynamic therapy have focused on the use of polymerbased nanoparticles for photosensitizer delivery systems. Nanoparticles containing photosensitizers have several advantages over photosensitizing molecules that are not encapsulated in nanoparticles. These advantages include a greater critical mass (concentrated photosensitizer packages) for the production of reactive oxygen species, limiting the ability of the target cell to pump the drug molecule out, thus reducing the possibility of multiple resistant drugs, selectivity of treatment by agents administration sites and the nanoparticle matrix is not immunogenic (4).

\section{CONCLUSÃO}

Finally, it is concluded after reviewing the literature, that the use of laser has been increasingly widespread in dental practices, not different in endodontics. Photodynamic therapy appears as a promising adjunctive therapy to conventional endodontic treatment, enabling the elimination of persistent microorganisms after the mechanical chemical preparation of the root canal system. However, a protocol has not yet been established in relation to the parameters to be used, confirming the need for more scientific research on the subject, however based on scientific articles, the following protocol is proposed for the use of photodynamic therapy in endodontics $(3,5,10.14)$ :

19) Conventional preparation of the root canal and at the end use of $17 \%$ EDTA.

2) Drying of the root canal.

3rd) Insertion of the photosensitizer (0.01\% Methylene Blue) for a period of 120 to 
180 seconds.

4th) Placement of the Diode laser with light length between 600-660 nm, for a period of 90 to 180 seconds, at an intensity of $100 \mathrm{~mW}$

5) Irrigation with irrigation solution to remove the dye.

\section{THE AUTHORS DECLARE NO CONFLICTS OF INTEREST.}

\section{REFERÊNCIAS}

1. Soares I, Goldeberg F. Endodontia: Técnicas e Fundamentos. 2 ed. Porto Alegre: Artmed; 2003.

2. Bassili L de O, Moraes IG de, Zanetti RV. Infiltração apical em obturações de canais realizadas após aplicação do laser Nd: YAG ou solução de EDTA nas paredes do canal radicular. J Appl Oral Sci. junho de 2003;11(2):102-6.

3. Arneiro RAS, Nakano RD, Antunes LAA, Ferreira GB, Fontes KBFC, Antunes LS. Efficacy of antimicrobial photodynamic therapy for root canals infected with Enterococcus faecalis. J Oral Sci. dezembro de 2014;56(4):277-85.

4. Pagonis TC, Chen J, Fontana CR, Devalapally H, Ruggiero K, Song X. Nanoparticle-based endodontic antimicrobial photodynamic therapy. J Endod. fevereiro de 2010;36(2):322.

5. Poly A, Brasil JFW, Marroig PC, Blei V, Risso P de A. Efeito antibacteriano dos lasers e terapia fotodinâmica contra Enterococcus faecalis no sistema de canais radiculares. Rev Odontol UNESP Online. agosto de 2010;39(4):233-9.

6. Lacerda LS, Floriano M, Campos CN, Ferreira Alfenas C. Terapia fotodinâmica associada ao tratamento endodôntico - revisão de literatura. RFO UPF [Internet]. abril de 2014 [citado 16 de setembro de 2017;19(1).

7. Siqueira MBLD, Lúcio PSC, Catão MHC de V. A terapia com laser em especialidades odontológicas. Rev Cuba Estomatol. 2 de maio de 2015;52(2):19-24.

8. Amaral RR, Amorim JCF, Nunes E, Soares JA, Silveira FF. Terapia fotodinâmica na endodontia: revisão de literatura. RFO UPF. agosto de 2010;15(2):207-11.

9. Alfenas CF, Santos MFL, Takehara GNM, Paula MVQ de. Terapia fotodinâmica na redução de micro-organismos no sistema de canais radiculares. Revistas. 7 de julho de 2011;68(1):68.

10. Garcez AS, Ribeiro MS, Tegos GP, Núñez SC, Jorge AOC, Hamblin MR. Antimicrobial 
Photodynamic Therapy Combined With Conventional Endodontic Treatment to Eliminate Root Canal Biofilm Infection. Lasers Surg Med. janeiro de 2007;39(1):59-66.

11. Castro MR, Brasil CO, Khouri S., Arisawa EAL. Avaliação in vitro do efeito da terapia fotodinâmica em suspensão de Enterococcus faecalis. $X$ Encontro latino americano de iniciação científica e VI Encontro latino americano de pós graduação. Universidade do Vale do Paraíba. 2006.

12. Asnaashari $M$, Homayuni $H$, Paymanpour P. The Antibacterial Effect of Additional Photodynamic Therapy in Failed Endodontically Treated Teeth: A Pilot Study. J Lasers Med Sci. 2016;7(4):238-42.

13. Eduardo C de P, Bello-Silva MS, Ramalho KM, Lee EMR, Aranha ACC. A terapia fotodinâmica como benefício complementar na clínica odontológica. Rev Assoc Paul Cir Dent. setembro de 2015;69(3):226-35.

14. Trindade AC, De Figueiredo JAP, Steier L, Weber JBB. Photodynamic Therapy in Endodontics: A Literature Review. Photomed Laser Surg. 26 de fevereiro de $2015 ; 33(3): 175-82$.

15. Machado AE da H. Terapia fotodinâmica: princípios, potencial de aplicação e perspectivas. Quím Nova. abril de 2000;23(2):237-43.

16. Konopka K, Goslinski T. Photodynamic therapy in dentistry. J Dent Res. agosto de 2007;86(8):694-707.

17. Mohammadi Z, Jafarzadeh H, Shalavi S, Kinoshita J-I. Photodvnamic Therapy in Endodontics. J Contemp Dent Pract. $1^{\circ}$ de junho de 2017;18(6):534-8.

18. Tennert C, Feldmann K, Haamann E, Al-Ahmad A, Follo M, Wrbas K-T. Effect of photodynamic therapy (PDT) on Enterococcus faecalis biofilm in experimental primary and secondary endodontic infections. BMC Oral Health. 4 de novembro de 2014;14:132.

19. Pinheiro Barcessat, A. R. . (2020). Tecnologia REAC: abordagem bioelétrica do processo saúde doença . Brazilian Journal of Implantology and Health Sciences, 2(13), 01-06. https://doi.org/10.36557/2674-8169.2020v2n13p01-06

20. Souza MA, Lima G, Pazinatto B, Bischoff KF, Palhano HS, Cecchin D. Evalution of antimicrobial activity of association of chlorhexidine to photosensitized used in photodynamic therapy in root canals infected by Enterococcus faceais. Photodiagnosis and Photodynamic Therapy.2017;19:170-4

21. Asnaashari M, Mojahedi SM, Asadi Z, Azari-Marhabi S, Maleki A. A comparison of the antibacterial activity of the two methods of photodynamic therapy (using diode laser 810 $\mathrm{nm}$ and LED lamp $630 \mathrm{~nm}$ ) against Enterococcus faecalis in extracted human anterior teeth. Photodiagnosis Photodyn Ther. março de 2016;13:233-7. 
22. Chrepa V, Kotsakis GA, Pagonis TC, Hargreaves KM. The effect of photodynamic therapy in root canal disinfection: a systematic review. J Endod. julho de 2014;40(7):891-8.

23. Silva FC, Freitas LRP de, Lourenço AP de A, Junior ACRB, Jorge AOC, Oliveira LD de. Análise da efetividade da instrumentação associada à Terapia Fotodinâmica Antimicrobiana e medicação intracanal na eliminação de biofilmes de Enterococcus faecalis em canais radiculares. Braz Dent Sci. 5 de agosto de 2011;13(1/2):31-8.

24. Ahangari Z, Mojtahed Bidabadi M, Asnaashari M, Rahmati A, Tabatabaei FS. Comparison of the Antimicrobial Efficacy of Calcium Hydroxide and Photodynamic Therapy Against Enterococcus faecalis and Candida albicans in Teeth With Periapical Lesions; An In Vivo Study. J Lasers Med Sci. 2017;8(2):72-8.

25. Asnaashari $M$, Ashraf $H$, Rahmati A, Amini N. A comparison between effect of photodynamic therapy by LED and calcium hydroxide therapy for root canal disinfection against Enterococcus faecalis: A randomized controlled trial. Photodiagnosis Photodyn Ther. março de 2017;17:226-32.

26. Borsatto MC, Correa-Afonso AM, Lucisano MP, Bezerra da Silva RA, Paula-Silva FWG, Nelson-Filho P. One-session root canal treatment with antimicrobial photodynamic therapy (aPDT): an in vivo study. Int Endod J. junho de 2016;49(6):511-8.

27. Garcez AS, Nuñez SC, Hamblin MR, Ribeiro MS. Antimicrobial Effects of Photodynamic Therapy on Patients with Necrotic Pulps and Periapical Lesion. J Endod. $1^{\circ}$ de fevereiro de 2008;34(2):138-42.

28. Prażmo EJ, Godlewska RA, Mielczarek AB. Effectiveness of repeated photodynamic therapy in the elimination of intracanal Enterococcus faecalis biofilm: an in vitro study. Lasers Med Sci. abril de 2017;32(3):655-61.

29. Bouillaguet S, Owen B, Wataha JC, Campo MA, Lange N, Schrenzel J. Intracellular reactive oxygen species in monocytes generated by photosensitive chromophores activated with blue light. Dent Mater Off Publ Acad Dent Mater. agosto de 2008;24(8):1070-6.

30. SCHAEFFER, Bárbara et al. Terapia fotodinâmica na endodontia: revisão de literatura. Journal of Oral Investigations, Passo Fundo, v. 8, n. 1, p. 86-99, abr. 2019. ISSN 2238-510X. Disponível em: https://seer.imed.edu.br/index.php/JOI/article/view/2779.

\section{DECLARAÇÃO CCBY}

SCHAEFFER, Bárbara et al. Terapia fotodinâmica na endodontia: revisão de literatura. Journal of Oral Investigations, Passo Fundo, v. 8, n. 1, p. 86-99, abr. 2019. ISSN 2238- 
510X. Available at: https://seer.imed.edu.br/index.php/JOI/article/view/2779. (30)

This copy is adapted for English and does not have the original authors 'address, except for the authorization of free sharing and free adaptation CC BY.

This is the license link for this article

https://creativecommons.org/licenses/by/4.0/deed.pt_BR .

This is the link to the original article

https://seer.imed.edu.br/index.php/JOI/article/view/2779. 